\title{
Public health for the hunter-gatherer in us all
}

\author{
Charles Gardner ${ }^{1}$ (1) $\cdot$ Donald C. Cole ${ }^{2} \cdot$ Loretta Ryan $^{3}$
}

Received: 17 January 2020 / Accepted: 11 May 2020 / Published online: 6 August 2020

(C) The Canadian Public Health Association 2020

\begin{abstract}
In evolutionary terms, the transformations which humans have engendered in social, ecological and built environments are increasingly out of step with their biological makeup. We briefly review the evidence on health-relevant practices and status of our Paleolithic ancestors and contrast these with current food, transportation, work and governance systems with their associated impacts on human health. As public health and planning practitioners engaged in the EcoHealth Ontario Collaborative, we argue for recognition of our hunter-gatherer nature to promote joint efforts in building sustainable and equitable community infrastructures, both built and green. Although such efforts are underway at multiple jurisdictional levels across Canada, the pace is frustratingly slow for the burden of endemic chronic diseases and global environmental change which humans face. Reminding reluctant stakeholders of the hunter-gatherers in us all could bring about deeper reflection on the urgent work in redirecting community planning.
\end{abstract}

\section{Résumé}

Sur le plan de l'évolution, les transformations que les humains ont apportées aux environnements sociaux, écologiques et bâtis sont de plus en plus en décalage par rapport à leur profil biologique. Nous examinons brièvement les données sur les pratiques et l'état de santé de nos ancêtres du Paléolithique et les comparons aux systèmes actuels d'alimentation, de transport, de travail et de gouvernance, avec leurs effets sur la santé humaine. En tant que praticiens de la santé publique et de la planification participant à la collaboration EcoHealth Ontario, nous plaidons pour la reconnaissance de notre nature de chasseurs-cueilleurs afin de promouvoir des efforts conjoints de construction locale d'infrastructures bâties et d'infrastructures vertes durables et équitables. Bien que de telles initiatives soient en chantier dans plusieurs administrations au Canada, leur rythme est désespérément lent vu le fardeau que représentent les maladies chroniques endémiques et les changements environnementaux mondiaux pour les humains. En rappelant aux acteurs réticents qu'au fond nous sommes tous des chasseurs-cueilleurs, nous pourrions susciter une réflexion approfondie sur l'urgence de réorienter l'aménagement urbain.

Keywords Paleolithic diet $\cdot$ Ecosystem $\cdot$ Exercise $\cdot$ Environment design $\cdot$ Urban planning $\cdot$ Environment and public health

Mots-clés Régime paléolithique $\cdot$ écosystème $\cdot$ exercice physique $\cdot$ conception de l'environnement $\cdot$ urbanisme $\cdot$ environnement et santé publique

Charles Gardner

Charles.Gardner@smdhu.org

1 Simcoe Muskoka District Health Unit, 15 Sperling Drive, Barrie, Ontario L4M 6K9, Canada

2 Dalla Lana School of Public Health, University of Toronto, Health Sciences Building, 155 College Street, Toronto, Ontario M5T 3M7, Canada

3 Association of Local Public Health Agencies (alPHa), 480 University Avenue, Suite 300, Toronto, ON M5G 1V2, Canada
For most of their 250,000 years, humans were huntergatherers, living off of what nature provided and they could procure (Richards 2002; Diamond 2013; Lieberman 2014) (see time periods, Box 1). As a consequence, the fossil record shows that our Paleolithic forbears rarely had cavities (Lieberman 2014) as their diets were largely devoid of simple sugars and starches (Richards 2002). Studying the way of life of current Indigenous hunter-gatherers is instructive (Walker 2001; Richards 2002; Lieberman 2014). Although child mortality for them is high (due to accidental injury and predation), the modal age of death among the adults is actually quite elderly-about 72 years (range 68-78 years) (Gurven and 
Kaplan 2007). They remain robust and productive until late into their lives, with chronic diseases being uncommon (Walker 2001; Gurven and Kaplan 2007; Lieberman 2014; Diamond 2013). In this commentary, we argue that more clearly recognizing our hunter-gatherer origins, ways of life and needs can inform ongoing debates about development pathways, sustainability and health.

Box 1 Humans' prehistory Stone Age periods with approximate, estimated dates

Paleolithic (or Old Stone Age) - 2.5 million years ago to 10,000 BC. Hunter-gatherers

Mesolithic (or Middle Stone Age)—10,000 to 8000 BC. Settling \& cultivation

Neolithic (or New Stone Age) - 8000 to 5000 BC. Agricultural food production

Variability across locations globally. Sources: https://www.history.com/ news/prehistoric-ages-timeline, https://www.inrap.fr/en/periods

\section{Origins of humans' biology systems mismatch and impacts on determinants of health}

Since the end of the last ice age some 12,000 years ago, a new agrarian way of life compromised the diversity and the sufficiency of human diets, while the large increase in food volumes stoked a dramatic surge in population size. In a cycle of recruitment, conquest and displacement, the ever larger, hierarchically organized agrarian populations supplanted the more egalitarian hunter-gatherer way of life (Lieberman 2014; Diamond 2013; Richards 2002). Analysis of the historic record demonstrates profound wealth and power disparity in all mass societies with the arrival of agriculture and material surpluses (Scheidel 2017). Increased proximity to domesticated animals led to zoonotic diseases, such as tuberculosis and the devastating smallpox (Lieberman 2014; Diamond 2013; Walker 2001; Richards 2002), similar to current viral pandemics. The fossil record shows that, compared with their Paleolithic forbears, Neolithic peoples were shorter in stature, with skeletal findings consistent with poorer nutrition and an increased prevalence of infectious diseases (Lieberman 2014; Richards 2002).

With the industrial revolution late in the eighteenth century came permanent, massive migration of rural populations into swelling cities. With concomitant resource extraction through colonialism and transformations in agricultural production globally, dramatic increase in overall macronutrients enabled a sufficient boost of material well-being for most in imperialist countries to regain the physical stature of the Paleolithic era (Lieberman 2014). Public health sanitation with municipal infrastructure investments (OPPI 2016) allowed most highincome country populations to regain a relative freedom from communicable diseases of the Neolithic era (Tam 2017). Yet years of life expectancy were lost as a result of the ultraprocessed diet and its correlate obesity (Nardocci et al. 2019), along with other industrial products such as tobacco and alcohol (Lieberman 2014). The mass marketing of the automobile in North America resulted in community urban design that demands its use to obtain the basics of human existence, whether acquiring food, or access to work, education or recreation (BCCDC 2018; OPPI 2016; Tam 2017). Impacts include road and pedestrian trauma, poor air quality and associated chronic diseases, and a massive carbon footprint (CPHA 2015; OPPI 2016). Populations in high-income countries now suffer from chronic diseases that are rarely seen even in the elderly years among hunter-gatherers (Gurven and Kaplan 2007). Both the agrarian and the urban ways of life have conflicted with our hunter-gatherer genetics and needs (Walker 2001; Richards 2002; Lieberman 2014).

\section{Understanding ourselves biologically as hunter-gatherers-what do humans need?}

We recognize that humans cannot go back to being huntergatherers en masse. Our numbers are too vast - at least 1000 times more numerous than the planet's carrying capacity for such a way of life (Diamond 2013). Furthermore, the way of life of hunter-gatherers was and is as varied as the many environments in which they have lived: tundra, open plains, deserts, seasides, tropical rainforests and more, such that no single "Paleodiet" existed (Walker 2001). Nevertheless, some common features of their ways of life have emerged (summarized in column 1, Table 1) (Walker 2001; Gurven and Kaplan 2007; Diamond 2013; Lieberman 2014).

As hunter-gatherers, we ate fresh, unprocessed foods which were generally accessible; we can approach this by going back to supporting farmers' markets and personal food production within residential neighbourhoods (CPHA 2015; Tam 2017; BCCDC 2018; OPPI 2016). As hunter-gatherers, we had moderate intensity physical activity most days. We can rebuild safe physical activity into our communities, and also dramatically reduce our carbon footprint through community design that emphasizes walking and cycling, as well as recreational public spaces and facilities (CPHA 2015; OPPI 2016; Tam 2017; BCCDC 2018). As hunter-gatherers, we daily experienced green spaces, wild or partly managed, on a daily basis, as many rural people still do. Relationships with other species were essential to hunter-gatherers, who kept moving so as not to compromise the ecosystem that sustained life and "all our relations" (McGregor 2010). Compact, green communities with attention to biodiversity could move us again in this direction (CPHA 2015; OPPI 2016). Hunter-gatherers spent much of their time with family and friends even when migrating (Gamble 1999). Supportive labour and employment 
Table 1 Hunter-gather livelihood characteristics and respective partner roles for change towards them

\begin{tabular}{|c|c|c|}
\hline \multirow[t]{2}{*}{ Hunter-gatherer characteristic } & \multicolumn{2}{|l|}{ Partner roles for change } \\
\hline & Municipal planning & Public health \\
\hline $\begin{array}{l}\text { Diverse diet, largely devoid of simple sugars } \\
\text { and carbohydrates, and low in salt }\end{array}$ & $\begin{array}{l}\text { Create community and personal food gardening, } \\
\text { grocery stores in every neighbourhood, and } \\
\text { farmers' markets }\end{array}$ & $\begin{array}{l}\text { Promote healthy food environments, restricting } \\
\text { the availability of highly processed, high salt } \\
\text { and sugar foods/drinks }\end{array}$ \\
\hline $\begin{array}{l}\text { Moderate to intense levels of physical activity } \\
\text { structured into their daily lives }\end{array}$ & $\begin{array}{l}\text { Design and modify/build infrastructure for active } \\
\text { transportation }\end{array}$ & $\begin{array}{l}\text { Activity promotion campaigns, provision of } \\
\text { evidence on the health benefits of active } \\
\text { transportation }\end{array}$ \\
\hline $\begin{array}{l}\text { Most time outdoors with daily exposure to the } \\
\text { natural environment, in a sustainable, } \\
\text { evolving ecosystem }\end{array}$ & $\begin{array}{l}\text { Protect green space-infrastructure, fund tree } \\
\text { planting, and work with ecosystem partners }\end{array}$ & $\begin{array}{l}\text { Encourage outdoor activities (with sun protection) } \\
\text { in collaboration with parks organizations and } \\
\text { other ecosystem partners; provision of evidence } \\
\text { on the health benefits of "green time" }\end{array}$ \\
\hline $\begin{array}{l}\text { Live in close proximity to extended family and } \\
\text { neighbours, providing communal support, } \\
\text { including for each other's children and the } \\
\text { elderly }\end{array}$ & $\begin{array}{l}\text { Design and modify/build community social } \\
\text { spaces, and more complete communities that } \\
\text { provide workplaces close to our homes }\end{array}$ & $\begin{array}{l}\text { Participation in community planning for age- and } \\
\text { youth-friendly communities; provision of evi- } \\
\text { dence on the lifelong health benefits from opti- } \\
\text { mal childhood nurturing }\end{array}$ \\
\hline $\begin{array}{l}\text { Egalitarian material resource distribution and } \\
\text { group decision-making }\end{array}$ & $\begin{array}{l}\text { Equity, diversity and inclusion policies and } \\
\text { participatory governance. Mixed housing } \\
\text { community design, and public transit systems } \\
\text { meeting the needs of all levels of income }\end{array}$ & $\begin{array}{l}\text { Advocacy for equity, diversity and inclusion } \\
\text { policies addressing social and ecological } \\
\text { determinants of health; provision of evidence } \\
\text { on health equity, and the social determinants of } \\
\text { health }\end{array}$ \\
\hline
\end{tabular}

Sources drawn upon: Column 1 (Walker 2001; Gurven and Kaplan 2007; Diamond 2013; Lieberman 2014) and columns 2 and 3 (EcoHealth Ontario 2017; Tam 2017; BCCDC 2018)

policies, working at home as in this COVID-19 pandemic, and providing workplaces close to homes, reducing commuting distances and travel time, could better foster such relationships (CPHA 2015; Tam 2017; OPPI 2016; BCCDC 2018). As hunter-gatherers, we had a more equitable distribution of material wealth and decision-making power, so now need stronger commitments to political processes that enable these (Janzen et al. 2018).

\section{Public health and municipal planning together}

Through the EcoHealth Ontario Collaborative, we have worked together to promote sustainable and equitable community infrastructures, both built and green, which can meet the needs of humans who still carry the genes of huntergatherers (see columns 2 and 3, Table 1). Urban planning that curbs the car culture and provides a full range of services and retail, including healthy fresh produce, social spaces and green spaces within walking distance of people's residence, along with well-developed active transportation and public transit systems is essential to the avoidance of chronic diseases (as well as injuries) and the promotion of mental health, healthy child development and quality of life (OPPI 2016; Tam 2017; BCCDC 2018). Official community plans have been reviewed for active living-related components and the impact of municipal transportation master plans on chronic disease incidence has been estimated (Arnason et al. 2019). Both public health and planning communities (private and not-for-profit, as well as municipal) have supported community planners, fostering improved health through walkable, cycleable, complete and compact community design (Tam 2017) and incorporating green space into community planning and investments (EcoHealth Ontario 2017).

\section{Persuading others to modify development models}

Yet the results of these efforts are frustratingly slow in an era of endemic chronic diseases (Tam 2017), global pandemics and global environmental change (CPHA 2015). With a dominant extractivist orientation, human societies continue to enact the sixth major extinction in our planet's history, prompting calls for the present era to be renamed the Anthropocene (i.e., the era of humans) (Hancock 2015). In response, public health thought has expanded to include the importance of ecology with multiple related terms being used (Buse et al. 2018), including ecohealth, one health and the ecological determinants of health (CPHA 2015), as well as led proposals for more fundamental eco-social transformation (Parkes et al. 2020). We would argue that recognizing the hunter-gatherers in us all is an important, additional conceptual tool to prompt deeper reflection on the urgent work needed in redirecting development of human societies and places. 
Understanding our Paleolithic Homo sapiens - hunter-gatherer selves - with our great longing for the forest and the ancestral village, can clarify a common vision of changes needed, and better motivate less enthusiastic stakeholders to alter destructive development pathways and promote both health and longer-term survival of humans and the ecosystems of which they are part.

Acknowledgements We acknowledge EcoHealth Ontario Collaborative for their support. We further acknowledge Sanja Hakkarainan, Administrative Assistant with the Simcoe Muskoka District Health Unit, who proofread the document, worked with SMDHU library services in the management of the references, and liaised with CJPH in the submission process for the paper.

Authors' contributions Charles Gardner initially conceived the commentary in discussion with co-authors, as part of a panel at an EcoHealth Ontario workshop. The first draft of the manuscript was written by Charles Gardner. Donald Cole revised it substantially and Loretta Ryan commented on various versions of the manuscript. All authors read and approved the final revised manuscript.

\section{Compliance with ethical standards}

Conflict of interest The authors declare that they have no conflicts of interest.

\section{References}

Arnason, T., Tanuseputro, P., Tuna, M., \& Manuel, D. (2019). Municipal transportation policy as a population health intervention: Estimating the impact of the City of Ottawa Transportation Master Plan on diabetes incidence. Canadian Journal of Public Health, 110(3), 285-293.

BC Centre for Disease Control (BCCDC). (2018). Healthy built environment linkages toolkit: Making the links between design, planning and health, Version 2.0. Vancouver, B.C. Provincial Health Services Authority. Available at: http://www.bccdc.ca/pop-public-health/ Documents/HBE_linkages_toolkit_2018.pdf. Accessed 26 August 2019.

Buse, C. G., Oestreicher, J. S., Ellis, N. R., Patrick, R., Brisbois, B., Jenkins, A. P., McKellar, K., Kingsley, J., Gislason, M., Galway, L., McFarlane, R. A., Walker, J., Frumkin, H., \& Parkes, M. (2018). Public health guide to field developments linking ecosystems, environments and health in the Anthropocene. Journal of Epidemiology and Community Health, 72(5), 420-425. https://doi.org/10.1136/ jech-2017-210082.

Canadian Public Health Association (CPHA). (2015). Global change and public health: Addressing the ecological determinants of health. Discussion Paper. Available at: https://www.cpha.ca/discussionpaper-ecological-determinants-health. Accessed 26 August 2019.

Diamond, J. (2013). The world until yesterday: What can we learn from traditional societies? New York: Penguin-Random House.

EcoHealth Ontario. (2017). Greenspace and ecohealth toolkit: Improving health and wellbeing through greenspace provision, design and access, prepared by Lura Consulting and Planning Solutions Inc. Available at: https://cleanairpartnership.org/cac/wp-content/ uploads/2017/04/Final-EcoHealth-Toolkit-March-30-2017.pdf Accessed 26 August 2019.

Gamble, C. (1999). The Palaeolithic societies of Europe (2nd ed). Cambridge: Cambridge University Press.

Gurven, M., \& Kaplan, H. (2007). Longevity among hunter-gatherers: A cross-cultural examination. Population and Development Review, 33(2), 321-365.

Hancock, T. (2015). Population health promotion 2.0: An eco-social approach to public health in the Anthropocene. Canadian Journal of Public Health, 106(4), e252-e255. https://doi.org/10.17269/CJPH. 106.5161.

Janzen, C., Marko, J., \& Schwandt, M. (2018). Embedding health equity strategically within built environments. Canadian Journal of Public Health, 109(4), 590-597. https://doi.org/10.17269/s41997-0180116-8.

Lieberman, D. (2014). The story of the human body: Evolution, health and disease. New York: Vintage Books.

McGregor, D. (2010). Honouring our relations: An Anishnaabe perspective on environmental justice. In J. Agyeman, P. Cole, R. HaluzaDeLay, \& P. O'Riley (Eds.), Speaking for ourselves: Environmental justice in Canada (pp. 27-41). Vancouver: UBC Press.

Nardocci, M., Leclerc, B., Louzada, M., Monteiro, C. A., Batal, M., \& Moubarac, J. (2019). Consumption of ultra-processed foods and obesity in Canada. Canadian Journal of Public Health, 110(1), 414. https://doi.org/10.17269/s41997-018-0130-x.

Ontario Professional Planners Institute (OPPI). (2016). Healthy communities and planning for the public realm: A call to action. Available at: https://ontarioplanners.ca/OPPIAssets/Documents/Calls-toAction/Healthy-Communities-and-Planning-for-the-Public-Realm. pdf. Accessed 26 August 2019.

Parkes, M. W., Poland, B., Allison, S., Cole, D., Culbert, I., Gislason, M. K., Hancock, T., Howard, C., Papadopoulos, A., \& Waheed, F. (2020). Preparing for the future of public health: The ecological determinants of health and the call for an eco-social approach to public health education. Canadian Journal of Public Health, 111, 60-64. https://doi.org/10.17269/s41997-019-00263-8.

Richards, M. P. (2002). A brief review of the archaeological evidence for Palaeolithic and Neolithic subsistence. European Journal of Clinical Nutrition, 56(12), 1270-1278. https://doi.org/10.1038/sj. ejcn.1601646.

Scheidel, W. (2017). The great leveler: Violence and the history of inequality from the Stone Age to the twenty-first century. Princeton: Princeton University Press.

Tam, T. (2017). The Chief Public Health Officer's report on the state of public health in Canada 2017: Designing healthy living. Public Health Agency of Canada. Available at: https://www.canada.ca/en/ public-health/services/publications/chief-public-health-officerreports-state-public-health-canada/2017-designing-healthy-living. html. Accessed 26 August 2019.

Walker, A. R. (2001). Are health and ill-health lessons from huntergatherers currently relevant? The American Journal of Clinical Nutrition, 73(2), 353-354. https://doi.org/10.1093/ajcn/73.2.353.

Publisher's note Springer Nature remains neutral with regard to jurisdictional claims in published maps and institutional affiliations. 